\title{
Recent Advances in the Treatment of $C$. difficile Using Biotherapeutic Agents [Corrigendum]
}

Giau VV, Lee H, An SSA, Hulme J. Infect Drug Resist. 2019;12:1597-1615.

Page 1599, Figure 1, the following copyright notice should have been included in the figure caption.

Adapted by permission from Springer Nature, Nature Reviews Disease Primers, Clostridium difficile infection, Smits W, Lyras D, Lacy D, et al, Copyright (C) 2016 (https://wtw.nature.com/nrdp). ${ }^{189}$
Page 1615, References, the following reference should have been included in the reference list.

189. Smits W, Lyras D, Lacy D, et al. Clostridium difficile infection. Nat Rev Dis Primers. 2016;2:16020. https://doi. org/10.1038/nrdp.2016.20

The authors apologize for these errors.

\section{Publish your work in this journal}

Infection and Drug Resistance is an international, peer-reviewed openaccess journal that focuses on the optimal treatment of infection (bacterial, fungal and viral) and the development and institution of preventive strategies to minimize the development and spread of resistance. The journal is specifically concerned with the epidemiology of antibiotic resistance and the mechanisms of resistance development and diffusion in both hospitals and the community. The manuscript management system is completely online and includes a very quick and fair peerreview system, which is all easy to use. Visit http://www.dovepress.com/ testimonials.php to read real quotes from published authors. 